University of Nebraska - Lincoln

DigitalCommons@University of Nebraska - Lincoln

Faculty Publications from the Harold W. Manter Laboratory of Parasitology

$10-1986$

\title{
Eulimdana rauschorum n. sp., a Filarioid Nematode (Lemdaninae) from Larus dominicanus in Antarctica, with Comments on Evolution and Biogeography
}

Eric P. Hoberg

United States Department of Agriculture, Agricultural Research Service, geocolonizer@gmail.com

Follow this and additional works at: https://digitalcommons.unl.edu/parasitologyfacpubs

Part of the Biodiversity Commons, Evolution Commons, Ornithology Commons, and the Parasitology Commons

Hoberg, Eric P., "Eulimdana rauschorum n. sp., a Filarioid Nematode (Lemdaninae) from Larus dominicanus in Antarctica, with Comments on Evolution and Biogeography" (1986). Faculty Publications from the Harold W. Manter Laboratory of Parasitology. 317.

https://digitalcommons.unl.edu/parasitologyfacpubs/317

This Article is brought to you for free and open access by the Parasitology, Harold W. Manter Laboratory of at DigitalCommons@University of Nebraska - Lincoln. It has been accepted for inclusion in Faculty Publications from the Harold W. Manter Laboratory of Parasitology by an authorized administrator of DigitalCommons@University of Nebraska - Lincoln. 


\title{
EULIMDANA RAUSCHORUM N. SP., A FILARIOID NEMATODE (LEMDANINAE) FROM LARUS DOMINICANUS IN ANTARCTICA, WITH COMMENTS ON EVOLUTION AND BIOGEOGRAPHY
}

\author{
Eric P. Hoberg \\ College of Veterinary Medicine, Oregon State University, Corvallis, Oregon 97331-4802
}

\begin{abstract}
Eulimdana rauschorum n. sp. is described from southern black-backed gulls, Larus dominicanus Lichtenstein in Antarctica. The species is most similar to Eulimdana lari (Yamaguti, 1935) from Charadriiformes in the Holarctic. Males have spicules equal in length that are asymmetric in structure distally. There are 4-5 and 3-5 caudal papillae in rows to the right and left of the anus, and 2 small genital papillae at the posterolateral margin of the anus. Females have a variable number of prominent caudal papillae and large microfilariae (365 $\mu \mathrm{m}$ in length). The morphological similarities and host distribution of $E$. rauschorum and $E$. lari suggest they are sister taxa in which cladogenesis of the former accompanied the isolation and subsequent speciation of Larus dominicanus in the Southern Hemisphere.
\end{abstract}

While conducting studies of parasite-host ecology among sympatric seabirds in the area of the Antarctic Peninsula, filarioid nematodes of the genus Eulimdana Founikoff, 1934, were collected from southern black-backed gulls, Larus dominicanus Lichtenstein. This is the second report of a filarioid nematode from Laridae in the Southern Hemisphere. Mawson (1969) partially described a female designated as Eufilaria sp. from Larus novaehollandiae Stephens in Australia. The present specimens from Antarctica appeared identical to that described by Mawson (1969) and were otherwise most similar to $\mathrm{Eu}$ limdana lari (Yamaguti, 1935) from Charadriiformes in the Holarctic. These relationships suggest the importance of ecological associations among marine birds, and coevolution with specific avian groups, in determining host and geographic distributions of these species of Eulimdana (see Bartlett and Anderson, 1980; Bartlett et al., 1985). In the present paper, Eulimdana rauschorum $\mathrm{n}$. sp. is described based on specimens from Larus dominicanus in Antarctica.

\section{MATERIALS AND METHODS}

Southern black-backed gulls and other species of seabirds were collected in the vicinity of the United States research base, Palmer Station, Anvers Island during the austral summer of 1982-1983. Birds were generally necropsied immediately following collection. Blood was collected, by heart puncture, from all species of charadriiforms. Smears were air-dried, fixed in absolute methanol, and stained with Wright's-Giemsa. Nematodes were fixed while alive in hot $(\sim 70 \mathrm{C}) 10 \%$ formalin or $70 \%$ ethanol $/ 5 \%$ glycerine and cleared in glycerine by

Received 12 September 1985; revised 12 December 1985; accepted 14 January 1986. evaporation. Enface mounts were prepared in glycerine jelly. The following description is based on observations and measurements from a maximum of 25 male and 30 female nematodes. All measurements are expressed as length vs. width in micrometers unless stated otherwise; ranges of measurements are followed by mean values in parentheses and some sample sizes are given as $(n=)$.

\section{RESULTS}

Nematodes were found in 9 of 21 adult gulls, but not in fledgling conspecifics or birds of 13 additional species including: Catharacta lonnbergi (Mathews), Catharacta maccormicki (Saunders), Chionis alba (Gmelin), Sterna vittata Gmelin, Pygoscelis adeliae (Hombron and Jacquinot), Pygoscelis papua (Forster), Pygoscelis antarctica (Forster), Oceanites oceanicus (Kuhl), Fulmarus glacialoides (Smith), Pagadroma nivea (Forster), Daption capense (Linnaeus), Macronectes giganteus (Gmelin), and Phalacrocorax atriceps King (Hoberg, 1983). The nematodes, orange when alive, were found immediately beneath the skin, in areolar connective tissue. Parasites were generally localized in the gular region of infected gulls, although several were found in the cervical and occipital areas. No host reaction was noted. Microfilariae were not observed in blood-smears.

\section{DESCRIPTION \\ Eulimdana rauschorum $\mathrm{n}$. sp. \\ (Figs. 1-10)}

General: Body robust, bent slightly ventrad; with thick cuticle. Anterior and posterior extremities blunt, rounded. Cephalic region slightly expanded, bulbous, divided asymmetrically into small ventral and large dorsal lobe. Mouth simple without oral cuticular inflations; bordered by 2 large lateral amphids; surround- 

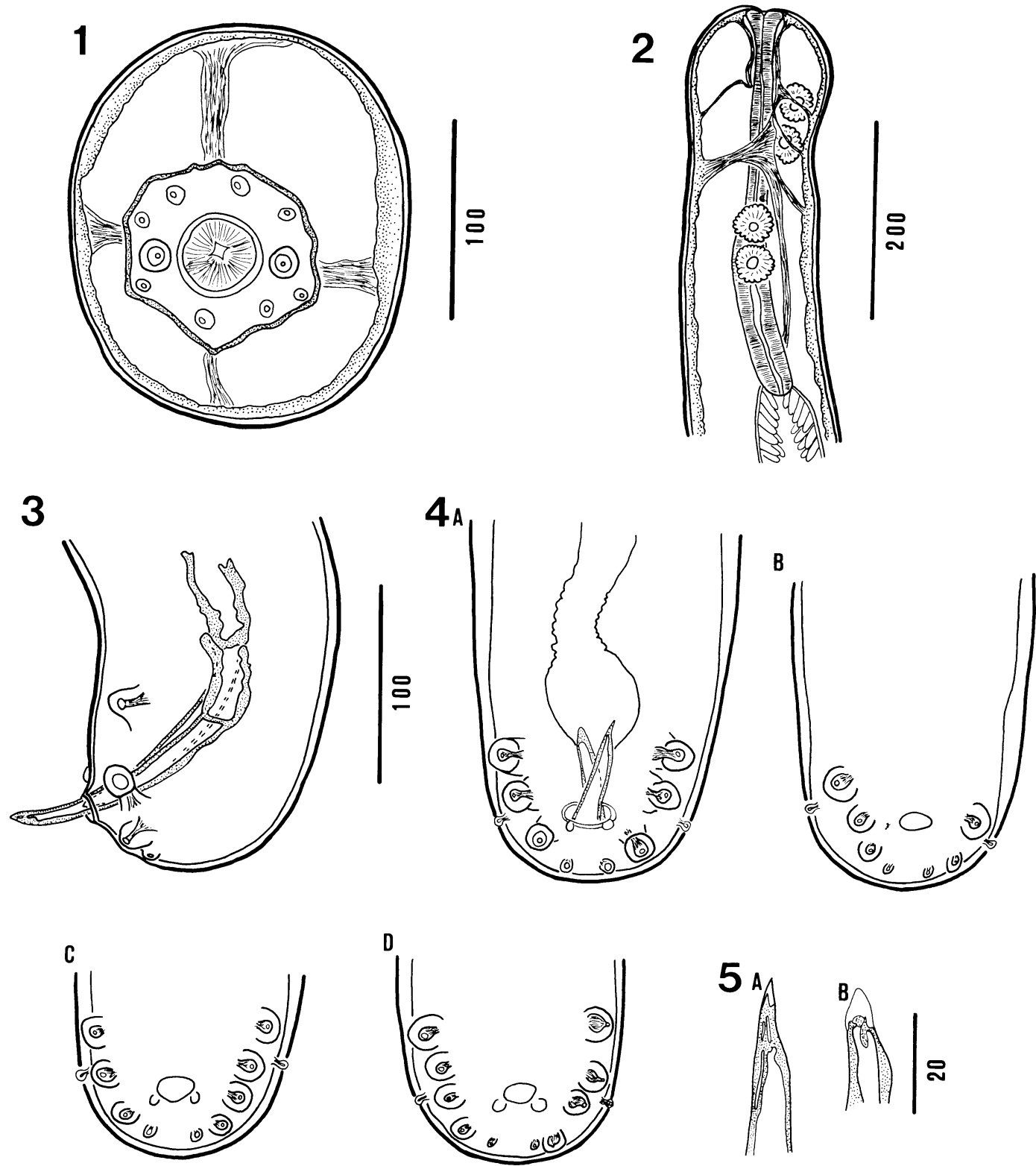

FIGURES 1-5. Eulimdana rauschorum n. sp. 1. Enface view, cephalic extremity of female, showing circumoral groove and papillae and lateral amphids. 2. Cephalic extremity of male, lateral view, showing prominent coelomocytes, esophagus and nerve ring. 3. Caudal extremity of male, lateral view, showing distribution of papillae and structure of spicules. 4A-D. Caudal extremity of male, ventral view, showing variation in number and distribution of anal and genital papillae (same scale as Fig. 3). 5A. Detail of tip of left spicule. 5B. Tip of right spicule.

ed by 4 pairs of small circumoral papillae distributed symmetrically in dorsal and ventral groups. Mouth and papillae surrounded by prominent circumoral groove. Cuticle with fine transverse striations. Irregular longitudinal thickenings of the cuticle sometimes evident. Male: Length $(\mathrm{n}=11) 3.5-5.8 \mathrm{~mm}(4.8)$. Width in cephalic region 127-155; at midbody 200-269; in caudal region 96-120. Nerve ring $(n=15)$ 116-177 (143) from anterior extremity. Excretory pore not observed. Esophagus $(n=14) 354-470(410)$ by 29-57 (38) at base; clearly demarcated from intestine; without appendix. Coelomocytes often prominent in esophageal 

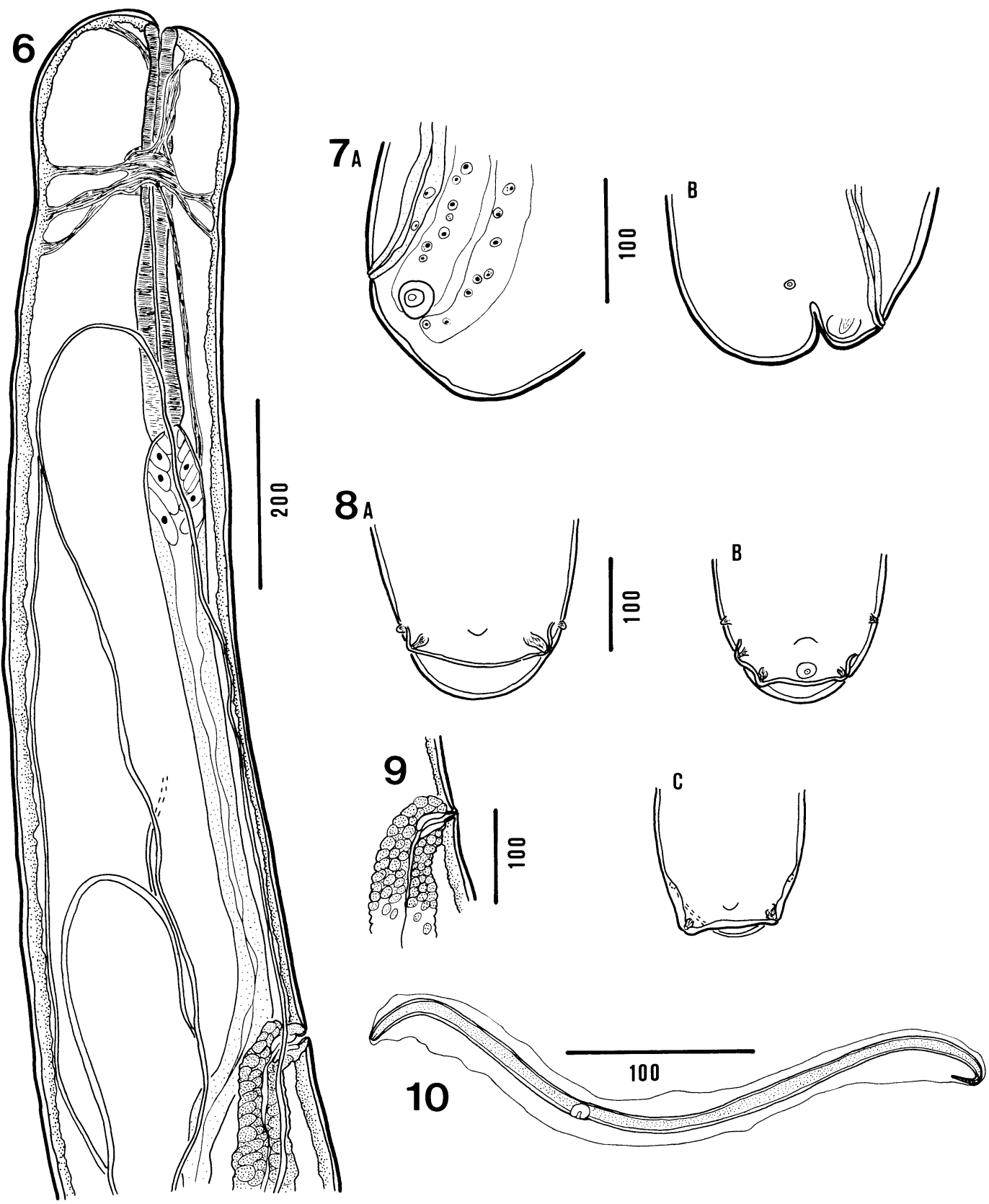

FIGURES 6-10. 6. Cephalic extremity of female, lateral view, showing relative position of nerve ring, ascending uterus, and vulva. 7A, B. Caudal extremity of female, lateral view, showing A) specimen with rounded tail, prominent longitudinal thickenings of cuticle, and large caudal papillae; B) specimen with posterior cleft. 8AC. Caudal extremity of female, ventral view, showing variation in number and distribution of caudal papillae, and position of anus. 9. Vulva, lateral view. 10. Ensheathed microfilaria from vagina.

region. Anus subterminal, 28-50 from caudal extremity; 2 small unstalked adanal papillae generally present at postero-lateral margin of anus. Large pedunculate caudal papillae in 2 rows lateral to anus; 4-5 papillae present on right side, and 3-5 on left. Spicules equal; asymmetric distally. Right spicule $(\mathrm{n}=10)$ 131-154 (144) long; tip blunt, conical, poorly sclerotized. Left spicule $(n=10)$ 131-157 (145); tip sharply pointed 
TABlE I. Comparison of Eulimdana rauschorum n. sp. with E. lari (Yamaguti, 1935) and Eufilaria sp. sensu Mawson, 1969.

\begin{tabular}{|c|c|c|c|c|c|}
\hline \multirow[b]{2}{*}{ Host-group: } & \multirow[b]{2}{*}{ Larinae* } & \multicolumn{2}{|l|}{ Eulimdana lari } & \multirow{2}{*}{$\begin{array}{c}\text { Eulimdana rauschorum } \\
\text { Larinae }\end{array}$} & \multirow{2}{*}{$\begin{array}{l}\text { Eufilaria sp. } \\
\text { Larinae }\end{array}$} \\
\hline & & Scolopacinae $\dagger$ & Phalaropodinaef & & \\
\hline \multicolumn{6}{|l|}{ Male } \\
\hline Body: length & $6.6-7.5 \mathrm{~mm}$ & $6.7 \mathrm{~mm}$ & $3.2-4.8 \mathrm{~mm}$ & $3.5-5.8 \mathrm{~mm}$ & \\
\hline width & $440-540$ & 320 & $204-231$ & $200-269$ & \\
\hline Esophagus: length & $380-540$ & 280 & $157-234$ & $354-470$ & \\
\hline Nerve ring $\|$ & - & 140 & $78-114$ & $116-177$ & \\
\hline $\begin{array}{r}\text { Spicules: length (L) } \\
\text { (R)\# }\end{array}$ & $155-170$ & $\begin{array}{l}130 \\
110\end{array}$ & $\begin{array}{l}117-138 \\
103-111\end{array}$ & $131-157$ & \\
\hline $\begin{array}{l}\text { No. caudal papillae (L) } \\
\qquad(\mathrm{R}) \boldsymbol{T}\end{array}$ & $\begin{array}{l}- \\
-\end{array}$ & 2 pair & $\begin{array}{c}4 \\
3-4\end{array}$ & $\begin{array}{l}4-5 \\
3-5\end{array}$ & \\
\hline Genital papillae & - & not observed & 1 , anteromedian & 2 , posterolateral & \\
\hline \multicolumn{6}{|l|}{ Female } \\
\hline Body: length & $9.8-11.7 \mathrm{~mm}$ & $10.8 \mathrm{~mm}$ & $7.1-18.1 \mathrm{~mm}$ & $7.6-12.3 \mathrm{~mm}$ & $11 \mathrm{~mm}$ \\
\hline width & $370-500$ & 480 & $234-600$ & $342-490$ & - \\
\hline Esophagus: length & $300-330$ & 300 & $195-410$ & $371-520$ & 450 \\
\hline Nerve ring $\|$ & $100-120$ & - & $96-180$ & $122-184$ & 200 \\
\hline Vulva\| & $400-650$ & 640 & $1.3-3.1 \mathrm{~mm}$ & $838-1,620$ & $1.1 \mathrm{~mm}$ \\
\hline Anus: position & terminal & terminal & subterminal & subterminal & subterminal \\
\hline Caudal papillae & - & absent & absent & 1-2 pair (variable) & 1 pair \\
\hline Microfilariae: length & 84 & - & $77-91$ & $325-406$ & $390-410$ \\
\hline $\begin{array}{l}\text { * Belopol'skaia (1952) males; Ya } \\
\text { † Sonin (1966). } \\
\text { ‡ Bartlett et al. (1985). } \\
\text { § Mawson (1969). } \\
\text { ॥ Distance from anterior extremi } \\
\text { \# Length of left (L) and right (R) } \\
\text { ॠ Number of papillae lateral to a }\end{array}$ & ules. & R) sides & & & \\
\hline
\end{tabular}

with complex sclerotized structure. Phasmids pedunculate, small, indistinct, ventral, subterminal. Alae-like structures on tail absent.

Female: Length $(\mathrm{n}=15) 7.6-12.3 \mathrm{~mm}$ (10.3). Width in cephalic region 140-214; at midbody 342-490; in caudal region $151-255$. Nerve ring $(n=18) 122-184$ (146) from cephalic extremity. Excretory pore not observed. Esophagus $(n=19)$ 371-520 (466) by 29-53 (44) at base. Vulva postesophageal $(n=20) 838-1,620$ $(1,216)$ from cephalic extremity. Vagina strongly muscular, 720-850 in length. Ovaries paired, opisthodelphic. Uterine limbs convoluted, maximum extent to nerve ring in anterior and to caudal extremity in posterior. Uterus with developing larvae in delicate thinshelled eggs $(n=50) 58-85(72)$ by $36-55(47)$. Anus patent, ventral, subterminal, 30-70 from caudal extremity. Caudal papillae prominent, lateral, seldom median; 2-3 on right side; 2 on left; occasionally single median, papilla present posterior to anus. Phasmids not observed. Caudal extremity usually with cleft, separating tail into dorsal and ventral lobes. Lateral chords with numerous nuclei.

Larvae: Ensheathed microfilariae $(\mathrm{n}=12)$ 325-406 (365) long, numerous in vagina; not observed in blood.

Type specimens: USNM Helm. Coll. No. 78761 holotype (male) and allotype (female) collected on Shortcut Island, 30 December 1982. Paratypes, No. 78762, male and 2 females with same data as holotype and No. 78763, 3 males and 2 females from type host on Limitrophe Island, 28 December 1982, by A. F. Betzel.

Type host: Larus dominicanus Lichtenstein. Also from Larus novaehollandiae Stephens (see Mawson, 1969).

Localities: Arthur Harbor, Anvers Island, Antarctica (including Limitrophe Island, Shortcut Island, and Bonaparte Point, ca. lat. $64^{\circ} 46^{\prime} \mathrm{S}$; $64^{\circ} 03^{\prime} \mathrm{W}$ ) (type). Also known from the Wauwermans Islands (ca. lat. $64^{\circ} 55^{\prime} \mathrm{S}$; $64^{\circ} 00^{\prime} \mathrm{W}$ ) and from Narrung, South Australia (see Mawson, 1969).

Habitat: Subcutaneous connective tissue of the esophageal region.

Etymology: The specific name rauschorum is established in honor of Robert L. Rausch and Virginia R. Rausch.

Comparisons: The genus Eulimdana was reviewed by Bartlett et al. (1985) and contains 4 valid species from avian hosts: Eulimdana clava (Wedl, 1856) (type) from Columbiformes and Passeriformes in the Holarctic, Asia, and Australia; Eulimdana micropenis (Travassos, 1926) from Selenidera maculirostris (Lichtenstein), a piciform in Brazil; Eulimdana heimi (Chabaud, Brygoo and Richard, 1964) from Coracopsis vasa (Shaw), a psittaciform in Madagascar; and E. lari (Yamaguti, 1935) from Charadriiformes in the Holarctic. Among these, E. rauschorum n. sp. resembles $E$. heimi in lacking super- and suboral cuticular inflations (Chabaud et al., 1964; Bartlett et al., 1985) but is most similar to $E$. lari when all characters are considered (Yamaguti, 1935; Belopol'skaia, 1952; Sonin, 1966; Bartlett et al., 1985).

Data comparing $E$. rauschorum and $E$. lari are presented in Table I. It is evident that there is a great 
degree of overlap in most measurements. Eulimdana lari has a broad host distribution in charadriiforms and there appears to be some degree of host-induced variation associated with specimens in Larinae (Yamaguti, 1935; Belopol'skaia, 1952), Scolopacinae (Sonin, 1966) and Phalaropodinae (Bartlett et al., 1985). This is manifested primarily in total body length, relative position of the vulva in females and possibly in length of the spicules in males. However, specimens of E. rauschorum and $E$. lari can be differentiated by a number of other characters.

In specimens of $E$. rauschorum, super- and suboral cuticular inflations on the cephalic extremity are absent and the mouth and cephalic papillae are bordered by a circumoral groove, in contrast to $E$. lari. Among females of $E$. rauschorum there are prominent caudal papillae and a caudal cleft, both absent in E. lari. The microfilariae of $E$. rauschorum are also exceptionally large, being 3-4 times the length of those reported for $E$. lari. Males differ in the number and distribution of caudal and genital papillae, and in the structure of the terminal portion and relative length of the spicules. In specimens of $E$. rauschorum there are more caudal papillae, 4-5 to the right and 3-5 to the left of the anus, and a pair of inconspicuous genital papillae at the posterior margin of the anus. In specimens of $E$. lari there are only 4 papillae in the right and 3-4 in the left row, and a single median genital papilla anterior to the anus. The spicules of $E$. rauschorum are similar in length while those of $E$. lari are unequal. The terminal portion of the spicules of $E$. rauschorum also appear more complex than those characteristic of $E$. lari.

Mawson (1969) described a female filarioid nematode, designated Eufilaria sp., from Larus novaehollandiae in Australia. Measurements of this specimen and those from $E$. rauschorum and $E$. lari are compared in Table I. Bartlett et al. (1985) indicated that this specimen could not be referred to $E$. lari, and the similarity with $E$. rauschorum is evident. The Australian specimen also has large microfilariae and caudal papillae; consequently, it is considered to be conspecific with $E$. rauschorum.

\section{DISCUSSION}

Eulimdana rauschorum n. sp. is currently the only avian-filarioid known from larids in Antarctica and the Southern Hemisphere. Filarioids appear to be relatively rare parasites of larids when considering the host-distribution of species in the 15 genera recognized by Anderson and Bain (1976) (Barus et al., 1978; Bartlett and Anderson, 1980). Eulimdana lari is the only species that occurs in representatives of most major subfamilies of Charadriiformes including larids.

Morphological similarities and host distribution of $E$. rauschorum and $E$. lari indicate close evolutionary affinities, suggesting these filarioids shared a common ancestor. Southern blackbacked gulls were apparently recently derived from the Larus fuscus L.-Larus marinus L. group of the North Atlantic and are generally related to the large white-headed gulls of the Northern Hemisphere (Moynihan, 1959; Voous, 1965; Schnell, 1970). Some of these Larus spp., including $L$. marinus, are known to be hosts for $E$. lari in the Holarctic. Thus it is probable that Eulimdana sp. was a parasite of large Larus-gulls prior to their isolation and divergence in the Southern Hemisphere. Cladogenesis resulting in $E$. rauschorum may have accompanied the speciation of $L$. dominicanus. The host and geographic distributions of some platyhelminth parasites in Larus spp. in the North Atlantic and $L$. dominicanus in South America and Antarctica support the concept for cospeciation of Eulimdana (Szidat, 1964; Stadler, 1975; Cielecka and Zdzitowiecki, 1981; Jarecka and Ostas, 1984; Zdzitowiecki and Szelenbaum-Cielecka, 1984).

Southern black-backed gulls have a broad geographic range in the Southern Ocean, including areas of South America, South Africa, Australia, New Zealand, the Subantarctic and Antarctica (Murphy, 1936; Fordham, 1963; Watson, 1975; Burger and Gochfeld, 1981). This distribution is largely allopatric to that of related Larus spp. of the Northern Hemisphere (Harrison, 1983). Consequently, an alternate but unsupported hypothesis for the distribution of E. rauschorum suggests colonization of $L$. dominicanus, and subsequent speciation, by Eulimdana sp. from other charadriiforms. Phalaropodinae and some Scolopacinae known as hosts for E. lari, particularly Charadrius hiaticula L., Calidris minuta (Leisler), Phalaropus lobatus (L.) and P. tricolor (Vieillot), are long-range migrants having wintering distributions extending beyond mid-latitudes in the Southern Hemisphere (Johnsgard, 1981; Cramp and Simmons, 1983). Thus there exists a potential for transfer of avian-filarioids from migratory charadriiforms to resident populations of larids, scolopacids and other avian groups that have similar habitat requirements in South America, Africa and Australia.

The broad geographic distribution of E. rauschorum in the Southern Hemisphere is indicated by its occurrence in $L$. novaehollandiae in Australia. Larus novaehollandiae and L. dominicanus are sympatric in some portions of their ranges in New Zealand, Australia and South Africa (Fordham, 1963; Pizzey and Doyle, 1980; Burger and Gochfeld, 1981). However, these species of gulls are not closely related, as Moynihan (1959) included $L$. novaehollandiae with the masked gulls of the Southern Hemisphere 
and $L$. dominicanus with the large white-headed gulls of the Northern Hemisphere. These relationships suggest that $E$. rauschorum colonized $L$. novaehollandiae when the 2 larids became sympatric. Such an association may be a further indication of the importance of community structure in determining the distributions of avian filarioids (see Bartlett and Anderson, 1980; Bartlett et al., 1985).

The extensive nature of the collections at Palmer, Antarctica (Hoberg, 1983) and the occurrence of $E$. rauschorum only in adult $L$. dominicanus indicates that infections probably were not acquired on the breeding grounds. Filarioids were not found as parasites of other charadriiforms, including Catharacta lonnbergi, C. maccormicki, S. vittata, and Chionis alba, sympatric with $L$. dominicanus in the region near Anvers Island. Either E. rauschorum does not have a broad host distribution, or the cycle of this filarioid cannot be completed in Antarctica due to harsh environmental conditions and lack of suitable vectors.

Eulimdana rauschorum could represent a component of a wintering ground parasite fauna. Migratory movements of $L$. dominicanus have not been well documented (Murphy, 1936; Watson et al., 1971; Parmelee et al., 1977; Bernstein, 1983), but some evidence indicates that young of the year birds disperse to South America (Bernstein, 1983). Juveniles and adults are known to form separate groups prior to autumn migration, but the extent and destination of any northward movements are unknown. Adult gulls are often sedentary in winter, and may be present in some areas during periods of ice-free water (Parmelee et al., 1977; Bernstein, 1983). Thus, if transmission of $E$. rauschorum occurs away from breeding colonies (possibly in South America) it may serve as a useful indicator of wintering areas for particular populations of southern blackbacked gulls from the western Antarctic.

\section{ACKNOWLEDGMENTS}

This research was conducted at Palmer Station, Antarctica during the austral summer of 1982-1983 and supported by a National Science Foundation Grant DPP 8115975 to Dr. R. L. Rausch and the author. Field studies were completed with the assistance of Dr. G. L. Shinn. Some birds were collected by Mr. Albert F. Betzel of the Division of Polar Programs, Mr. Bryan S. Obst and Dr. W. Hamner. I should also like to thank Capt. Pieter J. Lenie and the crew of the R/V Hero for logistical support in Antarctica. Additional assistance was provided by station personnel at Palmer.

\section{LITERATURE CITED}

Anderson, R. L., AND O. BAIN. 1976. CIH keys to the nematode parasites of vertebrates. No. 3. Keys to the genera of the order Spirurida. Part 3. Diplotriaenoidae, Aproctoidea and Filarioidea. Commonwealth Agricultural Bureaux, Farnham Royal, England, pp. 59-116.

Bartlett, C. M., AND R. C. Anderson. 1980. Filarioid nematodes (Filarioidea: Onchocercidae) of Corvus brachyrhynchos brachyrhynchos Brehm in southern Ontario, Canada and a consideration of the epizootiology of avian filariasis. Systematic Parasitology 2: 77-102.

, P. L. Wong, AND R. C. Anderson. 1985. Eulimdana lari (Yamaguti, 1935) n. comb. (Nematoda: Filarioidea) from Phalaropus spp. (Charadriiformes) in Canada and a review of the genus Eulimdana Founikoff, 1934. Canadian Journal of Zoology 63: 666-672.

Barus, V., T. P. Sergeeva, M. D. Sonin, ANd K. M. RYZHIKov. 1978. Helminths of fish-eating birds of the Palaearctic Region I. Nematoda. Junk, The Hague, 318 p.

Belopol'SKAIA, M. M. 1952. Parazitofauna morskikh vodoplavaiushchikh ptits. Leningrad Universitet Uchenye Zapiski. Seriya Biologicheskikh Nauk 141: 127-180.

BERNSTEIN, N. P. 1983. Influence of pack ice on nonbreeding southern black-backed gulls (Larus dominicanus) in Antarctica. Notornis 30: $1-6$.

Burger, J., AND M. Gochfeld. 1981. Nest site selection by kelp gulls in South Africa. Condor 83: 243-251.

Chabaud, A. G., E. R. Brygoo, and J. Richard. 1964. Filiaires des oiseaux malgaches. Annales de Parasitologie Humaine et Comparée 39: 69-94.

CiEleCKA, D., AND K. ZDZITOWIECKI. 1981. The tapeworm Microsomacanthus shetlandicus $\mathrm{sp}$. $\mathrm{n}$. (Hymenolepididae) from the Dominican gull of King George Island (South Shetlands, Antarctic). Bulletin de l'Académie Polonaise des Sciences, Série Biologique 29: 173-180.

Cramp, S., AND K. E. L. Simmons. 1983. Handbook of the birds of Europe, the Middle East and Africa. The birds of the Western Palearctic, Vol. III. Waders to gulls. Oxford University Press, Oxford, 913 p.

FORDHAM, R. A. 1963. Individual and social behavior of the southern black-backed gull. Notornis 10: 206-222.

HARRISON, P. 1983. Seabirds-An identification guide. Croom Helm Ltd., Beckenham, Kent, 448 p.

Hoberg, E. P. 1983. Preliminary comments on parasitological collections from seabirds at Palmer Station, Antarctica. Antarctic Journal of the United States 18: 206-208.

JARECKA, L., AND J. OSTAS. 1984. Hymenolepis arctowskii sp. n. (Cestoda, Hymenolepididae) from Larus dominicanus Licht. of the Antarctic. Acta Parasitologica Polonica 29: 189-196. 
JohnSGARD, P. A. 1981. The plovers, sandpipers and snipes of the world. University of Nebraska Press, Lincoln, Nebraska, 493 p.

Mawson, P. M. 1969. Some nematodes from Australian gulls and terns. Journal of the Fisheries Research Board of Canada 26: 1103-1111.

MoYNihan, M. 1959. A revision of the family Laridae (Aves). American Museum Novitates 1928: $1-42$.

Murphy, R. C. 1936. Oceanic birds of South America. American Museum of Natural History, New York, $1245 \mathrm{p}$.

Parmelee, D. F., W. R. Fraser, and D. R. NeIlson. 1977. Birds of the Palmer Station area. Antarctic Journal of the United States 12: 14-21.

Pizzey, G., AND R. Doyle. 1980. A field guide to the birds of Australia. Princeton University Press, New Jersey, $460 \mathrm{p}$.

SCHNEl, G. D. 1970. A phenetic study of the suborder Lari (Aves) II. Phenograms, discussion, and conclusions. Systematic Zoology 19: 264-302.

SonIN, M. D. 1966. Osnovy nematodologii. Tom 17. Filiariaty zhivotnykh i cheloveka i vyzyvaemye imi zabolevaniia. Akademiia Nauk SSSR. Izdatel'stvo Nauka, Moskva. 360 p.

STADlER, T. 1975. Clave para un problema. Antartida 6: $48-49$.
Szidat, L. 1964. Vergleichende helminthologische Untersuchungen an den argentinischen Grossmöwen Larus marinus dominicanus Lichtenstein und Larus ridibundus maculipennis Lichtenstein nebst neuen Beobachtungen über die Artbildung bei Parasiten. Zeitschrift für Parasitenkunde 24: 351-414.

Voous, K. H. 1965. Antarctic birds. In Biogeography and ecology in Antarctica. J. Van Mieghen, P. van Oye, and J. Schell (eds.). Junk, The Hague, pp. 649-689.

WAtson, G. E. 1975. Birds of the Antarctic and SubAntarctic. American Geophysical Union, Washington, D.C., $350 \mathrm{p}$.

, J. P. Angle, P. C. Harper, M. A. Bridge, R. P. SChlatter, W. L. N. Tickell, J. C. Boyd, AND M. M. BoyD. 1971. Birds of the Antarctic and Sub-Antarctic. Antarctic Map Folio Series 14: $1-18$.

Yamaguti, S. 1935. Studies on the helminth fauna of Japan. Part 12. Avian nematodes, I. Japanese Journal of Zoology 6: 404-431.

ZDZITOWIECKI, K., AND D. SZELENBAUM-CIELECKA. 1984. Anomotaenia dominicana (Railliet et Henry, 1912) (Cestoda: Dilepididae) from the Dominican gull Larus dominicanus Licht. of the Antarctic. Acta Parasitologica Polonica 29: 49-58. 